Journal of Social Sciences (COES\&RJ-JSS)

ISSN (E): 2305-9249 ISSN (P): 2305-9494

Publisher: Centre of Excellence for Scientific \& Research Journalism, COES\&RJ LLC

Online Publication Date: $1^{\text {st }}$ July 2015

Online Issue: Volume 4, Number 3, July 2015

http://www.centreofexcellence.net/J/JSS/JSS Mainpage.htm

\title{
THE UNITY OF THE YOUNG TURKISH AND TURKISTANISH FIGURES' EDUCATIONAL IDEAS AND PEDAGOGICAL CREDOS TO THE NATIONAL LIBERATION UPRISING (THE END OF XIX C. AND THE HEAD OF XX C.)
}

Kanat Bazarbayev, Sultanmakhmut Kipshakov, Assyl Manabayeva, Elmira Zulpiharova, Zhazira Baizhanova, Botagoz Nurmukhambetova

\begin{abstract}
:
The main goal of the motion of young Turkish men was to raise the education to the qualified level in exact politic activities with programmatic document concerning the social politic modernization in the country. The idea of improving an education that was formed in the process of young Turkish's educational activities was shown in the articles and speeches of figures who took an active part in this uprising. The educational ideas of young Turkish were developed in their own way. Because, the pedagogical ideas substantiated by the figures of young Turkish were the basis to form a national Turkey Republic. In M.K.Ataturk's state programs of forming new Turkey Republic the pedagogical ideas of young Turkish have been continued further on. Similar to this, it must be pointed out that the main peculiarities of an education in Turkestan region was the system opposed to an old education system which was the reason of increasing the number of ignorant people in Middle Ages and government power against chauvinism invasion.
\end{abstract}

\section{Keywords:}

Turkey, Turkestan, Middle Asia, supporters, young Turkish, national-liberation uprising, pedagogical credos.

\section{Citation:}

Bazarbayev, Kanat; Kipshakov, Sultanmakhmut; Manabayeva, Assyl; Zulpiharova, Elmira; Baizhanova, Zhazira; Nurmukhambetova, Botagoz (2015); The unity of the young Turkish and Turkistanish figures' educational ideas and pedagogical credos to the National Liberation Uprising (The end of XIX C. and THE HEAD OF XX C.); Journal of Social Sciences (COES\&RJ-JSS), Vol. 4, No. 3, pp:919-933.

http://dx.doi.org/10.17632/tndvmbwfhs.1 


\section{Introduction}

The president of our country Nursultan Nazarbaev on the $12^{\text {th }}$ of November declared a new economic policy of Kazakhstan "Nurly zhol". In extended meeting of "Nurotan" party in Astana the leader of the state said: "We took our national idea - an Eternal state as a main direction, we had turned our developing way of independence into a brilliant way". We must do our best in our Brilliant Way which has a bright future and requires a hard work. An Eternal Country - the united force of the country, source of power that never ends. It is not the ideological base of "Kazakhstan-2050" strategy but also it is the ideological pedestal of Kazakhstan in a XXI century! The new Kazakstanish patriotism is an Eternal Country! It is also the value of Kazakhstan society.

The notion of "An Eternal Country" involves not only the bow to the history, the pride to today's happiness and also belief to the blossoming future. To love the motherland is to respect the heritage inherited from our ancestors, to save, develop it and to pass on from one generation to another. "The source of "An Eternal Country" idea lies in deeply. For about 13 centuries ago Tonykok priest left a will that "The dream of Turkish people is an Eternal Country". It shows that that our national idea gets source from our ancient history. Above-ground did national idea, is unity your of Елдің. The unity of the state makes our national idea more viable. National ideas never realized where there is no consent and no agreement. The main reason of Kazakhstan's getting the top lies in its unity, consent and agreement", - said Nazarbaev to Kazakh people mentioning that having valued the constancy we got a success (Nazarbaev 2014).

He paid a great attention to the importance of developing national values in every person, to the necessity of the state unity and constancy which is based on giving equal right and possibility to every person without humiliating anybody, without rejecting anybody's language and religion.

Thus, from this point of view the research and analysis of pedagogical credos in developing education of young Turkish that expanded in the end of XIX century and in the head of XX century is of great importance. The famous academician of the Republic of Kazakhstan, known as "Ancestor Korkyt" in Turkish world, a great thinker, Rakhmankul Berdibaev in his works paid a special attention to the fact that the base of Turkish people is the same base, that the research of regularities of its differences and resemblances in epic legacy requires a great mental work (Berdibai 2002). In 1991 when the Republic of Kazakhstan got its independence the president of Turkey Republic Suleimen Demirel was the first who admitted Kazakhstan's independence and this proves our words. That is why, in future our cultural, economic and scientific connections with Turkey Republic should be more steady. Because, our national basis is the same, our opinions are the same. The pedagogical credos of young Turkish in developing education in the end of XIX century and in the head of XX century and it is necessary to research Turkistan's education turning into politic motion from historical and pedagogical point of view making thorough results. These two factors influenced directly on Turkistan's education turning into politic motion. In 1908-1916 in the process of raising a political motion in this region the growth of the national press could raise the political mentality of people. And in 1916 the squashing of national liberation uprising could raise political struggle to the new quality level, developed its strategic goals and tactic corrections. So, Turkistan national liberation motion became politically organized motion and prepared for a new changes in the country. 


\section{The influence of young Turkish on state education}

The revolution in 1908 gave a new dynamics to the development of culture and education in Turkey. The destruction of Abdulkhamit's authority liberated the development of sociopolitic and cultural life of people from the pressure of conservative traditions. That is why after the period of young Turkish's revolution it turned into the period of the formation of Turkish national mentality, formation of Turkish figures' national ideas and strengthening democratic values. In this period different scientific societies and organizations, which realized reforms, were formed and started to act. The new Turkish literature and leader strengthened. The revolution of young Turkish gave a new dynamics to an education. One of that incident's witnesses "The new steps in political life of 1909 is giving good results in school life now" (Zheltyakov, Petrosyan. 1965), - they wrote.

The French researcher Lui Bertran who went to Turkey after the revolution, noticed the great changes in schools of Turkey. He wrote that the changes in education became famous not only among the school children but also among teachers and professors, and they made all their efforts to activate the work of school (Zheltyakov, Petrosyan. 1965) From the very beginning young Turkish's party "Unity and Development" in its program documents paid a great attention to the problems of education. In most newspaper articles and books of that time there were a lot of ideas and opinions about the versatile development of education. As the main weapon of versatile development, the development idea of education was spreaded widely among the Turkish figures. In "Servet-i-finun" ("The wealth of knowledge") journal, publicated in 1895-1901 years, "The figures of new literature" played a great role in spreading these ideas widely among the people. This mission was continued by the society "Phedgry Ati" ("Star of the future") which was formed after revolution.However, in realization the reform there were some strains in solving the problems of international relations. As one of such erroneous steps, after the revolution young Turkish leadership tried to unite the Turkish schools and the schools of the less population nations with government authority. This opened politics of young Turkish to liquidate an independence of the schools of the less population nations was developed thanks to Osman empire's unity. So as this inappropriate politics about turkologizing through the assimilation of the nations involved in young Turkish empire doesn't coincide with the principles of reform, it met some difficulties.

As a result of a complex inner political struggle and a hard international condition of Turkey, they had to refuse from primordial plan of young Turkish and to take the principles of divided teaching of Muslims and Christians in primary school. In the program admitted by the young Turkish party in 1913 teaching Turkish language was obligatory in all primary and secondary schools and it was possible to teach Turkish in the mother tongue and this principle was admitted with this consent (Zheltyakov, Petrosyan. 1965).

Making the legal base of the problems of education in meeting was one of the reasons of discussion for several times. Nevertheless, to centralize or not to centralize Osman empire and to unite it to federal structure and such kind of complex problems in Mazhilis were the reason of not admitting the new laws concerning the schools. The law project which wasn't approved in Mazhilis in 1913 on the $23^{\text {rd }}$ of September, was planted as a "The temporary law of the primary education" by the command of the government. This law project run that a primary education in schools will be obligatory and free (Zheltyakov, Petrosyan. 1965). The following program of primary education in this law was approved: religious subjects (Kuran will be taught in muslim schools and others, and other religious subjects in schools organized for other different religions), reading and writing in native language, Turkish language, accounting and geometry, geography, history and natural 
science, economics, military science. In 1913 this law was devoted to reform only primary school. Nevertheless, in 1914 the start of the World War prevented this law realization which required a great deal of money. Before this law approved, the system of education in the state was formed on the basis of the law which was approved in 1896 and directions developed later.

In first years after the revolution of young Turkish the government was able to allocate a great deal of finance to education. Before the revolution, if 100-200 thousand lira was allocated to education, in 1908 to this field was allocated 442 thousand, in 1910946 thousand, and in 19121 million 148 thousand lira was allocated. Though the finance allocated to education was increased every time, its share in a budget was only $2-2,5 \%$ (Yьcel. 1938).

The government of the young Turkish paid its attention also to the development of partial secondary schools (idadie) within the primary schools. In 1910 they formed a committee to revise again the school programs of this level. There was a lack of qualified personnel in idadie schools as in primary schools.

As Kh.A.Yuzhel noted, the program for idadie schools wasn't poor, nevertheless, the problem of who would realize this program and how it would be realized was not solved (Yscel. 1938). The school programs dropped traditional muslim schools, the lack of teaching personnel was evident. The government of the young Turkish, the minister of Education Amrulakh Afandy noted that before the revolution only Galatasarai and Darusheffak lyceums paid much attention to enlarging the system of secondary education. On Amrulakh Afandy's initiative, they started to open lyceums on the basis of idadie schools in a number of big cities. The program of secondary school lyceums made in 1910-1913 was formed on the basis of French lyseums' programs and they teach there for 12 years. In the years of the I World War 11 lyceums were opened in the cities of Turkey such as Samsun, Adene, Eskishekhir, Antalia, Amasia, Kutakhe and others, 3 of them were opened for girls. After the revolution in 1908, one of the activities in school done by the young Turkish was the progress in the problems of teaching the girls. If taking into consideration, that before the revolution, muslim girls were within their right to take only primary education, then it can be guessed that the reform was directed to solve thoroughly the problems of equal rights of the women.

\section{The innovative reforms of the young Turkish government in education}

The innovative reforms of the young Turkish government in education included also the field of university. After revolution, the new programs of university faculties were worked out and they were completed with new subjects that raised qualities of teaching programs. An important index of university development was raised owing to increasing the number of the students admitted. If 40-60 people finished a law school in a year, in 1909 year 307 people, in 1914 year 256 graduates finished a law school. If long ago 30-40 graduates graduated from medicine faculty this time 275 graduated and in 1914 year 375 students graduated from medicine faculty (Bilsel. 1943).

In the years of after revolution universities started to send their students to Europe for practice. Also, from 1912 year the Turkish government invited a lot of German professors to Stambul university. This year 20 German professors worked in 3 faculties of university (Zheltyakov, Petrosyan. 1965). After 1908 year, within the aim of providing the education system of the school was paid a great attention to this problem. To the development of pedagogical college for men in Stambul, its director, an outstanding a Turkish educator Saty bey made a great his contribution. An academician V.A.Gordlevsky in his work "A teaching seminar in Stambul" noted that this college was a young Turkish's pride (Zheltyakov, Petrosyan. 1965). The opening of such kind of pedagogical institutions in 
Stambul could solve the problem of the lack of teaching personnel of the schools of a new type.

The young Turkish who took the authority, started to realize a number of reforms in inner policy of the country. They formed again a Turkish army and developed a German military system there. A military reform was realized according to general Dar Gols's directions. A modern weapons were delivered from German firms. Also, the young Turkish again formed the structures of zhandarmy and policy. One of surprising point is that the young Turkish were busy with strengthening their military punishment bodies in spite of the number of social and national problems not solved in the country.

Though the young Turkish promised to improve peasants' condition in the struggle against the authority of Abdulkhamit, after the victory of revolution they couldn't keep their promise. Nevertheless, in 1913-1914 they could admit a number of laws to solve agrarian problems. However, the start of the I World War didn't give any possibilities to realize this reform. The acts of the young Turkish in reforming education system were realized very hard because of the external invasion policy and inner political hostility. Nevertheless, the Ist World War destroyed the economic condition of the country and made the whole people to become a beggar. That is why, in all spheres of education system everything rolled down. In the Turkey Republic formed after the Ist World War the importance of continuing education reforms was great. In spite of these achievements the external force was the reason of young Turkish's motion destruction. It is necessary to search the reason of the young Turkish's motion in 1908 in the past periods before the revolution. On the whole, the revolution takes place in the result of the motions lasted for a long time. That is why, it's necessary to consider the start of the revolution before the years of reign formation of II Abdulkhamid sultan, or from middle XIX century. XIX century was the period not only of this revolution, but also it was the historical period of a number of famous events and changes from the point of view of Osman and Europe history. Generally speaking, the changes take place in XIX century influenced much on Osman state and was a jerk to the start of their renovation activities and also a jerk to the formation of the young Turkish revolution in the result of these activities. This process ended with the revolution in 1908.

Mainly, it is necessary to start the theme with the result of three important changes philosophical, political and economical changes, such as educational (XVII-XVIII ғF.), French revolution (XVIII ғ.) and industrial revolution (XIX ғ.) which take place in Western Europe. Educational philosophy opened the way to the development of "science and policy", French revolution to the formation of "new nation, state and army" and industrial revolution to "economical" achievements.

So, Western Europe was dominant among other states and nations. In the result of this process, the colonization policy that turned into the basic goal of the large states in Western Europe as England, France, Austria, Germany and Italy made a threat to other regions and people of the world (Alkan. 2009).

The most part of the regions that couldn't resist to the pressure of colonization states directly turned into their colony but others turned indirectly. The people from the captured places by these acts suffered from violence, scattered traditions about, owing mineral resources and wealth, they cruelly oppressed the people. There wasn't any country that didn't feel an influence of captured activities of Western Europe. So as the states such as Osman state, China, Japan and Iran with their state and military system felt that they were not able to oppose and they searched their way out from Western Europe. The renovation activities of some states, in the model of Western Europe, corresponds to one and the same time and the content of these activities was not an accidental event. All this led these 
countries to dangers. The events took place in Western Europe badly influenced on Osman state. These influenced events on Osman state were different in comparison with other regions and countries. So these changes took place in two opposite periods. The Ist period includes active actions of Osman state directed to attack the west. Indeed, from the very beginning taking the west, they considered their action as widening their land (Alkan. 2009).

After the 4 years World War the federal states (England, France, Belgium, Russia, Montenegro, Serbia) and America won the victory. Because of Osman army's defeat the chief minister Talat Pasha and his government broke up in 1918 on the $8^{\text {th }}$ of October. The duty to form a new government was given to Akhmet Izzet Pasha (3etiner. 2008). In a new government formed by Izzet Pasha, the members of "The Unity and Development" party Ali Fetkhi (Okiar) was appointed as the Minister for Internal Affairs, Zhavit Bei was appointed as the Minister of Finance, Khusein Rauf was appointed as Naval Affairs (Orbai).

Akhmet Izzet Pasha was a Minister of Military Affairs and Ismet Bei was appointed as a Counsellor of the Cabinet of Ministers. Izzet Pasha graduated from military school and military academy with honors diploma. Liman Von Sanders with Pasha influenced wrongly on close connection of Germans who sat in a German chief headquarter for a long time with the members of "The Unity and Development" party. Because of this political atmosphere the leader of "The Unity and Development" party decided to hold extraordinary congress. Эn 1918 on October 14-19 the congress was held, the problems of the congress were discussed. Doctor Nazym suggested that they would defend themselves on the court, being hidden for a long time in Andoly. The member of the "The Unity and Development" party Kara Kemal hoped the leading representatives (Ittikhat) of "The Unity" party go abroad and hoped to return home in a moment they would be calm.

Nevertheless, the major states in Europe had a dislike for members of "The Unity and Development" party. They disliked the ideas to enliven the state of Osman, to rebuild it. Эn their mind, the state of Osman had to be defeated, to be an easy target for them. The possession of the state of Osman was planned beforehand to be the possession of Christian countries or to be passed to newly formed independent countries. That is why, if "The Unity and Development" party didn't regenerate the state of Osman, whether they will reach their aim. That is why, they disliked "The Unity and Development" party.

Secondly, acievement of "The Unity and Development" party's goal was the model for figures of the major state. That is why, the countries such as India, Algeria or Egypt could say a motto that "The Unity and Development" party won in this revolution and we got our independence. Here we can accept Semikh Korai's concept that if "The Unity and Development" party would win it would prevent from the acts of colonization" (Ittihat terakki ve jцntbrkler. 2009).

The conference which was held in the honor of 100 year of the second Constitution in Turkey was devoted to evaluate the history of the young Turkish. So as the revolution of the young Turkish continues to live together with its supporters and opponents in policy stage, it was legal that there were whispers about different views on the theme. A number of such views strengthen the blame laid on "The Unity and Development" party more than before. The professor Semikh Korai in his report, made at this conference wrote that imperialism and its supporters who wanted to take away the Turkish revolution from the order of the day, so as they couldn't directly resist to Ataturk revolution, they attack thanks to "The Unity and Development" party. There were two aims of these attacks. The first aim is to slander all Turkish revolutions beginning with Ataturk revolution and take them away. The second aim is to put suspicious views to the hearts of the Turkish revolution 
participants. So, their ideas were to separate young Turkish's revolution from the national and democratic process that lasted for 150 years in our country and occupy them with suspicious views. In the result, there was a concept that it was evident that young Turkish's revolution had no concern to that moment's circumstance, and it became the problem that is observed by the historians who researched that period (Ittihat terakki ve juntbrkler. 2009). Though we support this concept, in the process of defining political and ideological influence of young Turkish's motion on the national-liberation motion of Middle Asia people we wanted to show that this motion turned into the phenomena that take an international importance.

\section{The first conditions of young Turkish's state management institutes}

In young Turkish's propaganda there was a concept that the management in constitutional model defended Turkey from foreign force's attack and formulates a free atmosphere. Thanks to Constitution, Turkey soon would turn to modern force which would manage on the basis of the law and constitution based on the principle of equality and brotherhood. The young Turkish made all the people believe in future, saying that "The new Turkey will go by its own way without taking any money from anybody, in the result of this the people of empire would be wealthy, and the state would be wholly independent economically and politically". In the country, after declaring a Constitution, on the young Turkish's demand, the sultan's irrade (amnesty) was declared for the participants of the revolutionary motion. This amnesty was concerned to more than 40 thousand politically prisoners and emigrants" (Aliev. 1972).

A great achievement of the young Turkish revolution is the achievement in organization a parliament. The program approved in 1908 in September, had to provide a victory in the elections of a Deputy Chamber (Mezhilisi Mebussan). To tell the truth, being elected of "Ittikhad ve Terraki" without any competition was very important. The oppositional party “Akhrar" (liberals) officially formed in 1908 \%. on September $14^{\text {th }}$ didn't strengthen fully as a separate independent political force (Aliev. 1972). Having successfully used this condition, the young Turkish let pass their own candidates to the Deputy Chamber and got a victory.

In the end of October in 1908 the elections have been finished, the first meeting of a Parliament started on the $15^{\text {th }}$ of November, 275 candidates were elected -142 Turkish, 60 Arabs, 25 Albanians, 23 Greeks, 12 Armenians, 5 Jewish, 4 Bulgarians, 3 Serbians, 1 kussoval. Before opening Mazhilis session, the names of 39 senators appointed by sultan had already been known. In 1908 on September $25^{\text {th }}$ Akhmed Riza Bei was appointed as a Chairman of the Parliament, his assistants were a Deputy elected from Adrianopol, Talat Bei and a Greek Deputy elected from Izmir, Aristidi Aphendi (Aliev. 1972).

The state management institutes formed by the young Turkish were the means provided the higher social layers' authority. Because young Turkish didn't understand the current problems of economical and political life of the people. They related to the external and internal policy of the people by the ideological point of view. For example, the leaders of "Ittikhad ve Terraki" took any decisions, they didn't pay much attention to realize it. The leaders of the young Turkish turned all state apparatus and the notion of law into the means of military, political leadership. That is why, within the authority of the young Turkish that went bankrupt, their political idealism's wholly defeat was not a seasonal situation (Aliev. 1972).

The young Turkish revolution left a deep track in political mind of non-turkish people of Osman empire. Their motto ("Freedom, equality and brotherhood") against sultan's despotism was accepted with enthusiasm of the people. The possibility of the revolution 
victory was because of such support of the young Turkish. Nevertheless, in the process of revolution osmanism ideas were wholly promoted, the interests of non-turkish people were crashed by chauvinism methods.

Though the young Turkish government's unity looked strong, there were political groups supported German, English and French directions among young Turkish.

In realizing panturkish plans, the people who supported Germany, hoped for the help of Germany and won in the struggle between these groups. They revenged Antanta power and wanted to get rid of their economical-political and military suggestion. Another situation was formed in the process of historical development, in the beginning of the first World War, the Osman empire that has a poor economic and financial condition was before wholly economic and military destruction. The leader of "Ittikhad ve Terraki" in such a situation had a political conflict. Such as Talat Pasha and other some young Turkish leaders, Zhavid bei, inclined to a separate agreement and "The affair of Yakub Zhamil" occurred because of such inner party contrasts.

The victory of Kazan revolution in Russia through the peace agreement with Turkey's Soviet Union gave a possibility to get rid of Imperialistic War. Nevertheless, instead of making such peace agreement, through the seizure of Transcaucasia, through the activity of "Sanitary cardon" which defends Turkey from Socialistic Revolution ideas, the young Turkish lost that possibility.

The military defeat of Turkey made the young Turkish be destroyed. The strengthened social forces were the main defendant of all difficulties of the people and turned away from the party "Ittikhad ve Terraki". The young Turkishs' going away from the authority was the first condition of making an agreement with Antanta people. The young Turkish revolution's achievements in internal and external policy in 1908-1918 years were enormous.

In the period of the young Turkishs' authority the leaders of muslim religion, especially, its supreme part remained as a group which used the advantages in Turkish society. The leaders of religion ruled for a great part of land (vakf), oppressed the workers cruelly. They did marketing with bread-staff and other products, and lived at the expense of the people. The religious people had a right to hold a religious sharia court, to gather religious taxes.

The Osman empire was a conglomerate state formed from different people and tribes that were at different stage of social economical and cultural development.

The state of empire type continued the high management comparatively. With the aim of leading these people the Abdulkhamit sultan administration starting with the use of past sultans' instructions, severe terror, grabbing, purchasing and all other devices. Supporting the principle of "Separate and start to rule", the sultan administration tried to save the empire setting one group of people to the other. Nevertheless, because of increasing the liberation motion, it turned into general dislike towards to the Turkish leader.

The young Turkish tried to unite all the elements dissatisfied by the living authority despite their political views. They couldn't provide their political unity with it. The diversity of social structure, ideological inequality, real political platform weakened the young Turkishs' society of "Ittikhad ve Terraki" and deprived them from peoples' supporting. Also, the young Turkishs' motion couldn't own the support of European progressive association. Because, they didn't believe this motion's aliveness and they believed that the way to realize Turkish reform would be under the direct control of the great power.

After the first Russian revolution the bourgeois revolution in Turkey in 1908-1909 years gave a new inflammable material for revolution covered the whole west countries. The 
events happened in Osman empire by the words of V.I.Lenin, "the inflammable material" spreaded all over the world. The fire would quickly spreaded over the most Asian states. In spite of reactionary actions of bourgeoisie, it is impossible to get rid of the expand of national revolution" (Ленин. 1961).

The young Turkish revolution had a great importance. This revolution cruelly defeated the despot monarchy of Abdulkhamit, it led to political struggle against the leaders of foreign capitalism. In 1908-1909 the Turkish revolution normalized the Constitution of 1876. In 1918-1923 against turkish people's imperialistic invasion and it gave a possible condition to national-liberation struggle in the way to destroy the power of Osman sultans. "Though the state governing mechanism of Ittikhad Turkey had a constitutional character, its importance didn't differ from Abdulkhamit power. One of the leaders of young Turkishs Talat Pasha said that that power was a humanization despotism" (Bilsel. 1943).

In XIX century in multinational Osman empire a lot of liberation motions took place. Nevertheless, those liberation motions were the Serbian, Greek and Bulgarian's struggle. And in 1908 Turkish people struggled against an individual power of sultan for the first time. In short, the young Turkish revolution was the first revolution to lead the way for Turkish people's political waking up. The motion of 1908 showed the strong and weak sides of Turkish people, prepared them for a new and successful arising. From this point of view, the young Turkish revolution destroyed the power of Abdulkhamit. It normalized the Constitution. It brings a new dynamics to social life. The historical role of Turkish revolution in 1908 is not in its defeat, but in its above mentioned success. It is appropriate to evaluate the young Turkish revolution not as a phenomena concluding a definite historical period, on the contrary, as a phenomena directed to a new period of Turkish history.

Because of the prevention of foreign states to make democratic changes of sultan II Abdulkhamit's despotic power in the state, foreign states despised Osman empire's possessions, the resistance of the actions directed on keeping it in economical and political independence was the main historical first condition of the formation of the young Turkish motion.

The formation of the young Turkish motion gave a possibility to take an organizational character for the struggle that was against colonizational invasion and feudalistic despotism in Osman empire. The political steps, organized by the administration of the young Turkish, directly influenced on the formation of political proof of the struggle and national ideas. In the result, at the beginning of XX century the young Turkish from the strong political current turned into a motion. Though the basis of the young Turkish motion were the young military workers who were very educated in Turkish society that time, the social base of the motion which was against colonization and feudalistic authority had a workers' support. Such social base may be said about the role of ethnic base in multinational Osman empire.

\section{The political-ideological formation of the young Turkish motion, services}

"The Unity and Development" party had an important role in the political-ideological formation of the young Turkish motion and its services. The political program appointed through a long-time experience of the party defined the young Turkish revolution's directions, put the basis of their political-social and cultural reforms. The organizational right and political content of platform formed by "The Unity and Development" party proved that it was the first democratic organization in the region of Asia in European model. 
In general, as the young Turkish motion's first historical conditions which took the source in the middle of XIX century, we would be convinced in the fact that there were the occurrence of the motion and factors influence on its formation. As the historical review concerning the theme shows, there are a lot of views concerning this problem. We came to the conclusion that the influence of the Ist Russian revolution (1905-1907 жж.) on the young Turkish motion was not strong. This groundless conclusion is evident from the fact that it didn't get any support from ideas in formation of the state structure of Turkey Republic.

From the young Turkish ideology's formation young Turkish political journalism turned into an influential factor in fully agitation it among the public. As a result, the ideas raised in the motion grew to the national level and was fully realized. The representatives of the young Turkish motion paid a great attention to the development of publication as a form of political struggle. A wide spreading of the young Turkishs' newspaper "Eki duynya" proves a lot of things.

Here is the reason of Anver Pasha's asking for publicating two newspapers in Turkish language, who accepted the united work of Soviet authority before the Political bureau of Central Committee of Russian Communist Party. So, it is evident that Anver Pasha wanted to activate this motion's experience.

As a high peak of young Turkish motion, the revolution in 1908 made the foundation of despotic authority of Middle century in Osman empire destroy. Also, it could put an obstacle in European states' political, economical invasion. It got an opportunity to activate reform not only from political, social and economical side but also from ethnic side. And this can be evaluated as the main achievement of young Turkish revolution.

In 1908 the aims of the young Turkish after political events in 1909 had some qualitative changes. Though the characteristics of these changes seemed far from democratic principles of social life, it served to put the interests of Turkish nation on the first place. Though this situation was a backoff in revolution, Turkey tried to form national statehood of Turkey.

The socio-political actions of young Turkish motion influenced a lot on formation of political idea and justification of national ideology. The revolution of young Turkish could fully feudalistic structure in Osman empire. The young Turkishs' indifference in solving radical problems in the country, in solving agrarian problems among them is characteristic to all periods of revolution of young Turkish motion's policy and ideology. One of the reasons of the young Turkish defeat was after revolution in 1908, to turn its own old social structure into a support of its dictatorship, struggling against feudal absolutism. The reactionary characteristic of the young Turkish authority was proclaimed by such signs. The actions of young Turkish motion at the end of XIX and at the beginning of XXI centuries turned into important period in socio-political life of Turkey. The most important in the process of the young Turkish motion in 1918-1923, was the main preparation of bourgeois national revolution that made Turkey turn into a modern state of a new type.

The acts of the young Turkish in reforming education system were realized very hard because of the external invasion policy and inner political hostility. Nevertheless, the Ist World War destroyed the economic condition of the country and made the whole people to become a beggar. That is why, in all spheres of education system everything rolled down. In Turkey Republic formed after the Ist World War, the importance of continuing education reforms was great.

Any society, any state differs its own general aims though it's based on general mankind values on its most educational ideas. Because of the peculiarities in a separate regions, socio-political and cultural development of the states it changes in a content. From this 
point of view, the main peculiarity of education in Turkestan region was the opposition system of old education system to chauvinism invasion. These two factors influenced directly on Turkistan's education turning into politic motion.

\section{The formation of cultural educational ideas in Turkestan region}

It is evident that cultural education in its developing process turned into political education. Political education together with justifying the arguments of oppositional struggle to colonization power through influence on choosing the methods of this political struggle could define the strategy of Turkestan national-liberation motion. For jadits aimed at educating people in Turkestan region, turning the motion into political direction, in its turn, as in Turkish society the muslim unity idea raised on the policy stage. These political directions, first of all, in the process of reforming the colonization power with the methods of democracy, raised political demands to the level of national idea.

We connect the start of political period of Turkestan national-liberation motion with the elections of the Ist Russia State Duma. Because, in the process of preparing for these elections, the nation figures of this region for the Ist time started to divide into groups on political ideas. After this period, the jadit motion started to take political characteristics and through the impact of the Central Council of Russian muslims went out from regional level and enlarged their service. In the process of raising political motion in the region in 1908-1916 years, the growth of national publication could raise the people's political mind to the high level. And crushing of national-liberation motion in 1916 lifted political struggle to the new qualitative level, and developed corrections to its strategic goals and tactic devices. By this, Turkestan national-liberation motion had a political organizational character and prepared for a new changes in the country.

The impact of political shakes covering the whole Russia, covered Turkestan region also. Democratic origins of February bourgeois revolution stimulated political forces in the region to new beginnings. Especially, socio-democratic organizations tend to formation of power structures equivalent to Turkestan Committee of Temporary Government. Such political intention in the period of colonization power, was formed on chauvinism intention and hoped to realize it through crushing the interests of local people. So as such political intention was formed on the base of chauvinistic character in colonizational authority there was a hope to realize peoples' interests through crushing it. In its turn, the national political organizations and motions in the region, formed urgently came to one conclusion what authority would Turkestan have in an updated Russian society, and started to raise the problem of forming an autonomous structure in the region. Though the national forces in the region supported Turkestan Committee of Temporary Government, they couldn't come to a general agreement in defending a national interest. And, the group ideas suggested by socio-democratic organizations were not accepted and suggested by the national forces. The representatives of the national elite who were at the top of political motion in the region continued its struggle to reach an autonomous independence which had to be the source of Turkestan regional independence. Turkestan uprising was formatted as a regional phenomena and had an international characteristics by the content peculiarities and by the external influence. Especially, Turkestan achievements, reached by the raised political ideas and the ways of their realization, defines the content individuality of the motion.

Turkestan national-liberation uprising didn't limit by the regional volume and it turned into an international phenomena by the characteristic, content and its influence. Because, the direct and indirect influence of foreign national-liberation uprising for its ideological and organizational formation is defined by the historical facts. It is necessary to say about the influence of the young Turkish motion among the direct influenced factors. The 
historical analysis, facts and well-grounded proofs give a possibility to make such conclusions. The development of Turkey and Turkestan relations by the non-official ways in the end of XIX century and at the beginning of XX century impacts on the development of these relations. It was known that these relations were developed by these ways: first of all, the connections of figures who got an education in Turkey and went there with different aims: this direction was the base of jadit, muslim and Turkish ideas development. Secondly, the relations between Turkish military prisoners of Turkestan and a military men started by Anver Pasha. This direction impacts on the development of the struggle in Turkestan motion. Thirdly, Turkey turned into a Turkestan's political emigration centre. This direction opened the way to the period of emigration of Turkestan motion.

Though there were inter dispute concerning some problems between Turkish emigrants in foreign countries, they were umanimous in the struggle for Turkestan's independence. In general, the organization "The national unity of Turkestan" could play an important role in propagandizing the unity of Turkish people and their independence as a main idea of Turkestan national-liberation motion. The Soviet power didn't consider with the local people intentions of independence and it created an uprising towards to encroachment of soviet power. Though Turkestan national-liberation motion was defined as the period of strong struggle, though there were different views on the struggle, it played an important role in Turkestan national-liberation motion.

As the analysis of Turkish Middle Asian historiography had shown the assessment of Anver Pasha's role in the history, it was evident it had a contradictory character

And the views on his participation in Turkestan national-liberation motion were of this character. According to the results of our research we come to the conclusion that Anver Pasha was the supporter of the armed forces in Turkestan national-liberation motion. Together with Turkestan national-liberation motion, the necessity of considering the personality of Anver Pasha who influenced on the fate of representatives of Kazakh national elite M. Shokai, S. Kozhanov, G. Birimzhanov, D. Adilov and other figures, was evident. (Shokai. 1998).

The connections of the young Turkish with Turkestan national-liberation motion were shown in their individual representatives' activities. For example, the activities of Turkestan's figures such as Munuar Kary, M.Shokai, S.Lapin, Ubaidulla Khozhaev, Z.U.Togan and Turkish Anver Pasha, Subkhi. Such personality relations strengthen the interconnection of two motions' political relations and gravity (Shokai. 1998).

As the results of the research shows, it is evident that there were resemblances in the formation and development of young Turkish motion and Turkestan national-liberation motion. In general, the regularities that are the base of the development of nationalliberation motions are characteristic to both of these motions. The resemblances of these two motions were defined as follows:

1. A Middle century social institutes' turning into a braking force in the socio-political development in Osman empire and Turkestan region. And exactly, being behind of the educational system, obsolescence of traditional socio-political relations, if this situation took place in Osman empire and Middle century authority structures that hold the despotic power of Abdulkhamit II would be shown, in Turkestan the traditional society of ruler government colonizational power and instead of renewing reactionary institutes with an assertiveness characteristic to Russian empire were shown as strengthening chauvinistic, colonizatory structures 2 . The basis of occurring and formation of two motions was the source of an educational ideas. In the result, the educational ideas in both motions were of the national direction character. 
3. There were ideological interconnections accepted in the program documents of political motions that based the proofs of liberational motion and formate the national ideas in two motions. The ideological interconnections were clearly noticed in comparison with the resemblances in the structures of political organizations. For example, there were a lot of resemblances in political principles of the party "The Unity and Development" and the motion "Shuroi Islamiya", also between the parties "Akhrar" and "Shuroi Ulema".

In spite of these resemblances, there were a number of peculiarities in the young Turkish motion and Turkestan national-liberation motion. These peculiarities get the source from the fact that Turkey was an independent state and Turkestan was a colony of powerful Russia. Because of this situation, political aims and objectives of these two motions were shown from its realization tactics and strategy. To this problem in Turkey they directed to get rid of the influence of the despotic power of Abdulkhamit II and the colonizational actions of foreign states, this situation was shown as a disposal from a modernization of the Middle century social structure in Turkestan and a colonizational pressure. According to this, young Turkish put the idea of forming a new Turkish state instead of Osman empire on the first place. And the young Turkishs' this idea was realized in the process of the socio-political changes in Turkey. The leaders of Turkestan national-liberation motion, who were under the political and military pressure of the Soviet authority, accept the national state structure and the ideas of getting the independence with timidity. Though the Soviet authority in Turkestan was formed, it should be pointed out that the connections of Turkey-Turkestan were not lost, on the contrary it had a new content. We can be sure that there were concrete actions to impact ethnopolitical process in Turkestan in the process of political connections between the Soviet authority and Turkey. Nevertheless, these connections that had to strengthen national-democratic values in reinforcing totalitarian system, were lost.

\section{Methods}

The authors referred to the achievements of modern historical sciences in theoreticalmethodological basis of the research work. An individual persons' socio-political activity of a national-liberation motion, induction and deduction, historical-comparative, systematic-structural, theoretical cognition and other general scientific research methods were used and concluded in the process of the research historical events and phenomena. The political history requires to take into account the different and contradictory condition of political-ideological phenomena when making conclusion the idea of historical-political and socio-cultural arguments. That is why, variability of the research object, such peculiarities as their connection and inner independence were taken into account.

In the research, the method of restoration through falsification of a definite conclusions or historical analysis that adds the knowledge in traditional historical cognition, was used.

\section{Conclusion}

In historical period, the historical connections of Kazakhstan Republic and Turkey Republic were considered in the research work in different aspects. But, we want to point out that it is the first research that considered historical connections of two states from the influence of the national-liberation at the beginning of XX century and political motions. We came to this conclusion, having made an analysis to the research that considered the young Turkish motion and Turkestan national-liberation motion in the Soviet historiography, also the historiographical analysis of the foreign researchers' works.

The actions of the young Turkish in reforming the system of education realized very hard because of the external invading policy and inner political hostility. Nevertheless, the Ist World War destroyed the economic condition of the country and made the whole people 
to become a beggar. That is why, in all spheres of education system everything rolled down. In the Turkey Republic formed after the Ist World War the importance of continuing education reforms was great. In spite of these achievements the external force was the reason of young Turkish's motion destruction.

As the results of the research showed, the main goal of the motion of young Turkish men was to raise the education to the qualified level in exact politic activities with programmatic document concerning the social politic modernization in the country. The idea of improving an education that was formed in the process of young Turkish's educational activities was shown in the articles and speeches of figures who took an active part in this uprising. And these ideas were in the government and parliament's attention, formed by the young Turkish.

Nevertheless, we can't say young Turkishs' educational ideas were behind and were not finish, judging by the young Turkishs' unfinished motion. Because, pedagogical ideas based by the young Turkish figures found its continuation in the next period of the motion that formed the basis of forming Turkey Republic.

In M.K.Ataturk's state programs of forming new Turkey Republic the pedagogical ideas of young Turkish have been continued further on.

We connect the start of political period of Turkestan national-liberation motion with the elections of the Ist Russia State Duma. Because, in the process of preparing for these elections, the nation figures of this region for the Ist time started to divide into groups on political ideas. After this period, the jadit motion started to take political characteristics and through the impact of the Central Council of Russian Muslims went out from regional level and enlarged their service. Similar to this, it must be pointed out that the main peculiarities of an education in Turkestan region was the system opposed to an old education system which was the reason of increasing the number of ignorant people in Middle Ages and government power against chauvinism invasion. These two factors influenced directly on Turkistan's education turning into politic motion. In 1908-1916 in the process of raising a political motion in this region the growth of the national press could raise the political mentality of people. And in 1916 the squashing of national liberation uprising could raise political struggle to the new quality level, developed its strategic goals and tactic corrections. So, Turkistan national liberation motion became politically organized motion and prepared for a new changes in the country.

It is evident that cultural education in its developing process turned into political education. Political education together with justifying the arguments of oppositional struggle to colonization power through influence on choosing the methods of this political struggle could define the strategy of Turkestan national-liberation motion.

Coming to the conclusion, the pedagogical credos of young Turkish and the representatives of Turkestan national-liberation motion in developing education in the end of XIX century and in the head of XX century and through researching new steps from historical and pedagogical point of view, making thorough results, we decided to make a little contribution to the field of history. 


\section{References}

Nazarbaev, Nursultan. (2014). «Nurly zhol - is a way to the future» the message of the President of Republic of Kazakhstan to the people of Kazakhstan. The newspaper Egemen Kazakhstan. Astana. Elorda.

Berdibai, Rakhmankul. (2002). All we are Turkish. - Astana: Pholiant. 177-344p.

A.D.Zheltyakov, Yu.A.Petrosyan. (1695). History of education in Turkey (the end of XVIII - the beginning of XX century). Publishing house «Nauka». The main edition of eastern literature. Moskow.

Yscel. (1938). Torkiede Orta цpretim. Эstanbul.

C.Bilsel. (1943). Эstanbul sniversitesi tarihi. Эstanbul.

Necmettin, Alkan. (2009). Mutlakiyetten Meюrutiyete II Abdblhamid ve jцn torkler 18891908.Istanbul. I-baskэ.-339. s.

Selahattin, 3etiner. (2008). Зцkью yэllarэ. II Abdblhamit, jцn tbrkler, ittihat ve terakki. Remzi Kitabevi. Ankara.-318 s

Ittihat terakki ve jцntьrkler. 2009. Kaynak yayэnlarэ. Birinci Basэm: Istanbul. -147 s.

Aliev G.Z. 1972. Turkey in the period of the young Turkish. (1908-1918 yy.) Publishing house «Nauka». The main edition of eastern literature. Moskow.-388 p.

Lenin V.I. 1961. Combustible material in the world policy.// Full collected works. Moskow. - T. 17.

Shokai, Mustafa. Selected. 2 t. 1-t. -Almaty: Kainar. -252 p. 